SCADide

Infer, Interpret \& Inspire Science
International Journal of Forensic Science \& Pathology (IJFP)

ISSN: 2332-287X

\title{
Study of Prevalence of Pattern Arch in Right Index Finger of Indian Males for Assisting Fingerprint Analysts in Expediting Criminal Identification
}

SINGH Surender Pratap ${ }^{1 *}$

${ }^{1}$ Retd. Dy. Supdt. (Finger Print), Central Finger Print Bureau, NCRB, New Delhi, India.

Abstract

The basic fingerprint patterns were described by Dr. Francis Galton in his book-Fingerprints, published in 1892, but prior to that Dr. Henry Faulds, in 1880, had promulgated the idea of linking visible Scene of Crime prints with the perpetrator, and recording of impressions on paper. The thumb and the index of the dominant hand are the most used fingers for accomplishing routine to explicit tasks, thus the latents found at the place of occurrence, often include these two digits. The initial process of criminal identification involves recording suspects' prints, and their comparison with the lifted latent/s. If the pattern of the latent/s is decipherable, then the expert uses it as a clue, to exclude or include exemplars. However, the chance prints are usually partial, and in the absence of fixed points, it is particularly difficult to distinguish between a whorl and a loop pattern. As there are no recurves, core and delta, it's relatively easier to recognise the pattern arch from a fraction of the latent. Thus, having better indication of prevalence of arches in Right Index (RI) finger of Indian males, can assist the analysts in expediting the process of identification, by reducing the numbers of specimen slips/cards to be included for comparison. In this study 2000 fingerprints, or 200 ten-digit fingerprint slips were examined to calculate the prevalence of arches in adult Indian males. There were 77 numbers, or 3.85\% arches, detected in 2000 prints, and their percentage frequency in RI finger of 200 subjects was $10.00 \%$.

Keywords: Arch; Fingerprint Slip; Scene of Crime; Latents; Comparison.

\section{Introduction}

Although basic pattern classification, description \& use of ridge characteristics for identification, was explained in detail by Dr Francis Galton in 1892, but it was Dr. Henry Faulds, who in 1880, had already promulgated the idea of linking blood prints (visible finger marks) at the crime scene with the culprit. He had also recommended the use of Printers' Ink for recording the finger impressions on paper for comparison and identification of the offenders [1].

In this paper it is intended to determine the trend or the prevalence of a rare pattern type i.e., Arch in Right Index (RI) finger of Indian males, because along with thumb, it is one of the most applied or used digits, in accomplishing routine to special tasks. It may have comparatively higher chances of sourcing the latents found at the scene of crime, perhaps better than thumb, due to its strategic positioning in a hand (i.e., thumb is smaller in length and is placed perpendicularly, and stays at sufficient gap from Index finger in normal circumstances). Although the prime emphasis is on the Right Index (RI) finger, but the frequency of the pattern arch in Left Index (LI), and other fingers of hands too was studied, so as to have a better insight into the whole scenario. Fingerprints of women have not been included in this study, because during random pick-up of 10-digit spare slips from the records, the number of such slips was insignificant. For a logical or justifiable study, the number of subjects of both genders should either be equal, or in proportion with the gender ratio of the country, otherwise the results may lead to confusion rather than clarity on the issue under consideration.

(i) Exclusion / inclusion of suspects' prints by pattern type found at the Scene of Crime (SoC)

When an analyst or a fingerprint technician visits the scene of crime for processing (i.e., detection, development and lifting of

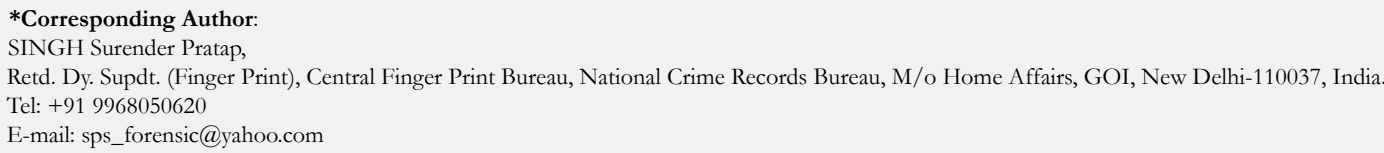

Copyright: SINGH Surender Pratap 2021. This is an open-access article distributed under the terms of the Creative Commons Attribution License, which permits unrestricted use, distribution and reproduction in any medium, provided the original author and source are credited. 
latent/s), s/he follows a sequence or protocol. Once the lifted print reaches the table of a fingerprint expert, it is examined to confirm its origin. After confirming it source from human friction ridge skin (there are other mammals who have fingerprints similar to human beings), it is carefully observed to ascertain whether image reversal is required during photography; application of wrong powder during development can lead to ridges appearing white/light coloured and furrows appearing dark or black. In such event image reversal is undertaken during photography, so that the ridges and furrows have appropriate colour, and contract with the background. Then, the examiners use their skills to determine the area of friction ridge skin that formed the latent, whether it is part of the sole, palm, distal, middle or top phalange of the finger. Next, comes the determination of pattern type (arch, loop, whorl etc.), but ascertaining a pattern from a partial impression is not always an easy chore, especially in cases of missing fixed points (delta and core). However, it is comparatively easy to identify an arch pattern, even from a fractional SoC print, as the arches do not possess recurves, and fixed points.

It may sound easy, but identification is a time consuming and tedious process, involving many steps or levels. Moreover, sometimes there can be huge number of suspects' slips, and the latent developed and lifted from the place of occurrence is fractional. Sometimes, after hours-n-hours of comparison, experts find all the exemplars NOT-IDENTICAL or DIFFERENT, then they might have to further probe/investigate and add more suspects in the list for comparison. There are many occasions, when the culprit is not from the list of suspects, then the chance print is compared against the old records, manually or through Automated Finger Print Identification System (AFIS). In AFIS too final identification/verification is done by human experts only. So, studying the trend or percentage frequency of a rare pattern, Arch, in Right Index finger of Indian males, is an effort to give fingerprint examiners, a small cue or a hint to assist in their decision to exclude or include prints for comparison, from the huge collection of suspects' slips/cards. The trend or information on prevalence will not only ease them of work overload, by faster exclusion of bulk of specimen slips (with no arch pattern/s), but also assist in expediting the overall sequential process of fingerprint-based identification.

If a fingerprint is encountered as evidence, matching of minutiae is the secondary task, the primary task being the classification (i.e., arch, loop, whorl etc.) of the pattern present on the print, which can thereafter be used for narrowing down the suspect pool by eliminating the suspects with any other pattern type other than the one found on the crime scene and hence reducing the burden on the investigating officer [2].

An analyst comparing a crime scene print to a print on the file would first gather known prints with the same general pattern type, then using loupe (portable magnifier), compare prints sideby-side to identify specific information within the minutiae that match. If enough details correlate, the fingerprints are determined to be from the same person [3].

\section{(ii) Distribution of Arches in Human Population}

In the 19th, 20th, and 21st century there have been a very few major studies in which more than 500 (five hundred only) individuals or 5000 (five thousand only) fingerprints, were included for determining the percentage frequency of digital friction ridge patterns. First it was conducted in 1892 by Dr. Francis Galton, then in 1905 by the Scotland Yard, London, UK, later at the Central Finger print Bureau (CFPB), Calcutta, India in 1953. [4, 5].

Lakshamanan \& Bhoi (2014) had reported that in 2006, four AFIS (Semi/Automated Fingerprint Identification System) based studies involving a total of 70,82,040.00 individual fingerprints were conducted, and it was found that the cumulative percentage frequency of Arches was $3.319 \%$.[6]. Another study by Banik et al (2009), where prints of 207 males and females were analysed, the percentage frequency of Arches was calculated at $1.14 \%$ only [7].

It is a generally believed that the arches make up about $5.0 \%$ of all pattern types. But is it actually the case, do they constitute five percent of all pattern types in fingers of the world's human population? Perhaps studies have been offering inconsistent findings, it's not just about the current studies, even Dr. Francis Galton in his analysis of 1892, involving 5000 finger marks, calculated the relative percentage frequency of Arches at $6.50 \%$. The results of the studies, undertaken by the Scotland Yard Committee (1905) London, UK, and the Central Finger Print Bureau (CFPB), Calcutta, India (1953), with a data size of 50000 impressions each, were more or less similar, the percentage frequency of Arches was found to be 4.86 , and 4.83 respectively, Although, the prevalence of Arches reported by the above two leading agencies were close

Table No.1. Percentage Frequency of Arches in Human Population [4-6].

\begin{tabular}{|c|c|c|c|c|c|}
\hline S. No. & Patter Type & $\begin{array}{c}\text { 1892, Dr. Francis } \\
\text { Galton } \\
\mathbf{( 5 0 0 0 ~ P r i n t s )}\end{array}$ & $\begin{array}{c}\text { 1905, Scotland } \\
\text { Yard Committee, } \\
\text { London, UK } \\
\text { (50000 Prints) }\end{array}$ & $\begin{array}{c}\text { 1953, CFPB, } \\
\text { India } \\
\text { (50000 Prints) }\end{array}$ & $\begin{array}{c}\text { 2006, AFIS } \\
\text { Aggregate of four studies } \\
\text { (70,82,040 Prints) [6] }\end{array}$ \\
\cline { 2 - 6 } & \% Frequency & \% Frequency & \% Frequency & \% Frequency \\
\hline 1 & Arches & 6.50 & $4.866 \%$ & $4.838 \%$ & $3.319 \%$ \\
\hline 2 & Loops & 67.50 & $69.696 \%$ & $69.414 \%$ & $56.350 \%$ \\
\hline 4 & Whorls & 26.00 & $20.066 \%$ & $19.83 \%$ & $28.947 \%$ \\
\hline 5 & Composites & - & $5.372 \%$ & $5.486 \%$ & $10.285 \%$ \\
\hline 6 & $\begin{array}{c}\text { Amputated or Indeci- } \\
\text { pherable }\end{array}$ & - & $25.4385 \%$ & $25.316 \%$ & $40.530 \%$ \\
\hline 7 & Scar & - & $0.498 \%$ & $0.42 \%$ & - \\
\hline
\end{tabular}


to $5.00 \%$, but there have been many studies reporting varied percentage frequency of arches.

\section{Rationale of the Study}

Along with the Thumb, Index is a finger which is most often used in accomplishing common as well as, specific tasks; then comes the Middle Finger, which in terms of in-dispensableness, would rank only after Index or the Fore-finger/First finger. Thus, in comparison to other fingers, the marks of these three fingers, of the dominant hand, would probably be found more often at the scene of crime. If we further condense this list, then the chances of getting latents of the Thumb, and the Index finger (on the basis of indispensability), shall possibly be encountered in more instances, in contrast to other fingers of the dominant hand, by the crime scene analysts. As majority of Indians are right-handed (over $92.00 \%$ ), or use right hand as their dominant hand, thus it was felt pertinent to study the prevalence of Arch in Right Index (RI) finger, as a means to aid the investigators for making quicker decisions to include or exclude the specimen slips, and reduce the overall time of the process of identification. Furthermore, the prevalence or trend of such a rare pattern on a particular finger, can give the analyst a cue about the probability or chances of identifying the perpetrator from amongst the specimen slips or fingerprint records.

\section{Handedness of Indian Population}

Unlike Europe and America, the number of left-handed persons in India is far less, a website Leftyfretz.com, after compiling data of such persons for several years, reported in 2009 , that only 5.20 $\%$ of Indian population is left-handed. While the Netherlands, the United States, and Canada, had 13.23\%, 13.10\%, and $12.80 \%$ population which respectively used left as their dominant hand. [8].

In a more recent study by Allu \& Chakrabarti in 2020, involving 500 adult Indian male and female students, in the age band of 18 to 25 years, it was observed that majority i.e., $92.2 \%$ of all participants were Right-handed, whereas, only $7.8 \%$ were Left-handed. Whereas, in case of only males, 228 (nos.), or $92.68 \%$ were Righthanded, and 18 (nos.), or $7.3 \%$ were Left-handed. Furthermore, in case of only females, 233 were Right-handed and 21 were left-handed. In 228 Right-handed males, they found 24 (nos.), or $10.5 \%$ Arches in the First digit or Index (Right Index) finger. In left-handed males, there was only 01 (no.), or 5.5\% Arches in the Index (Left Index) finger [9].

\section{Objective}

To study percentage prevalence of pattern Arche in Right Index (RI) finger of Indian males, for aiding fingerprint analysts in their decision making on selecting suspects' prints for comparison, and expedite the overall process of criminal identification.

\section{Materials and Methods}

\section{Data \& Data Collection}

The Central Finger Print Bureau (CFPB) of the National Crime Records Bureau (NCRB), New Delhi, India, receives two types of 10-digit finger print slips; the slips for record, and the slips for search, from the States (Provinces) and the Union Territories of the country. The Record slips, carry personal and conviction details, along with finger impressions of all 10-digits of hand, while the Search slips possess impressions, demographic details, and information about crime, but no information on conviction/ sentence for the offence.

Many a times the States/UTs send more than the required copies of the fingerprint slips to the CFPB, and at the Bureau, such slips are marked, 'Spare', and kept aside (in the trays or bunched together as bundles) for shredding/discarding. They are also used for imparting training \& preparing training material. Two hundred spare slips were picked-up randomly, they included both 10-digit slips for Record, and Search. Damaged/torn, slips with incomplete or missing finger impressions (rolled \& plain), were not included for the study.

In this paper the terms, latents, or latent prints have been used repeatedly as synonyms for all types of chance prints/scene of crime prints (visible, invisible and plastic).

Data collection and compilation was done from September2018 to November 2018 (three months).

\section{Representation of Population}

The 18 States/UTs were included in the study through the 10-digit fingerprint slips received at the Central Finger Print Bureau, New Delhi, in the form of slips for record and search. The names of 18 States/Union Territories of India included in the study are as under:

1. Assam (AS), 2. Meghalaya (ML), 3. Himachal Pradesh (HP),4 Chandigarh $(\mathrm{CH})$, 5. Chhattisgarh (CT), 6. Delhi (DL), 7. Haryana (HR), 8. Madhya Pradesh (MP), 9. Punjab (PB), 10. Uttar Pradesh (UP), 11. Rajasthan (RJ), 12. Goa (GA), 13. Gujarat (GJ), 14. Karnataka (KA), 15. Maharashtra (MH), 16. Orissa (OR), 17. Tamil Nadu (TN), 18. West Bengal (WB).

\section{Operational Definitions}

1. Fingerprint Slip for Record: The form containing 10-digit rolled impressions and plain prints taken in proper sequence for record with particulars regarding name, parentage, residence, conviction, etc. of a convict is called a Finger Print Slip for record [10].

2. Fingerprint Slip for Search: Similar form with 10-digit impressions when used for search to trace previous conviction from the record of the Bureau is called Finger Print slip for search [10].

3. Arch: A pattern type in which the friction ridges enter from one side of the impression and flow, or tend to flow, out to the other side without turning back, with a rise or wave in the middle. Arch patterns are found in two types, the plain and the tented. The tented arch is shaped like a tent or volcanic mountain; the ridges near the centre of the base have upward thrust [11].

4. Scene of Crime (Place of Occurrence): A crime scene is any location that may be associated with a committed crime [12]. The location of a crime scene can be the place where the crime took place or can be any area that contains evidence 
from the crime itself [13].

5. Latents or latent Print: Friction ridge detail not generally visible to the naked eye and must either be enhanced by development powders or by physical and / or chemical treatments. In general parlance amongst the crime scene technicians/ analysts, all SoC prints are referred as latents (visible or invisible).

6. Comparison: It is when two or more impressions are compared to determine the level of agreement between two areas of friction ridge skin and to establish the existence of discrepancies or similarities. The second step of the ACE-V test process [14].

7. ACE-V Method of Identification: The Process for identifying latent fingerprints, which involve Analysis, Comparison, Evaluation, and Verification. This is a sequence process of determining whether the questioned print/latent/scene of crime fingerprint is identical with the exemplar or the specimen print. It is most widely used approach of identification of fingerprints across the world.

8. Identification: It is the determination of the ridge characteristics in the questioned and the specimen fingerprint, to declare that the two prints are from the same source (individual/person).

\section{Results \& Discussion}

In this section the results of the present (current/this) study will be examined to ascertain the prevalence of arches in Right Index
(RI) and other fingers of Indian people, the findings of this study will also be compared with the results of other major studies conducted in India, for validation.

\section{Percentage frequency of Arches calculated in Ten fingers of Hands in Present Study (2021)}

As displayed in the table given under (i.e., Table No. 2), in the present study, there were a total of 77 (seventy-seven) arches found in 2000 finger impressions, or 200 ten-digit finger print slips of Indian human males, representing 18 States/Union territories of India. The percentage frequency or prevalence of arches in 2000 individual prints of Indian male subjects was calculated, and found to be $3.85 \%$.

In the Table No. 3, there are many interesting aspects, the researches may like to note while analysing the results, of the some of which are:

- The overall prevalence of arches in the Left Hand is slightly higher than Right Hand.

- The number of arches in Right Index (RI) and Left Index (LI) is the highest.

- The number of arches in Ring and Little finger of both hands, is the least (Nil in Right Little in this study).

- The number of arches in Middle fingers was higher than Ring and Little fingers.

Table No. 2. The percentage frequency of pattern arch in 2000 digits/fingers.

\begin{tabular}{|c|c|c|c|c|}
\hline $\begin{array}{c}\text { States/UTs included in the } \\
\text { study }\end{array}$ & $\begin{array}{c}\text { No. of 10-digit } \\
\text { Fingerprint slips } \\
\text { of male subjects }\end{array}$ & Total No. of Prints & $\begin{array}{c}\text { No. of Arches (Plain \& } \\
\text { Tented) in total no. of prints }\end{array}$ & $\begin{array}{c}\text { Percentage of Arches } \\
\text { (plain \& Tented) in } \\
\text { total no. of prints }\end{array}$ \\
\hline $\begin{array}{c}\text { 10-digit Fingerprint Slips from } \\
\text { 18 States/Union Territories of } \\
\text { India }\end{array}$ & 200 & 2000 & 77 & 3.85 \\
\hline
\end{tabular}

Table No. 3. Percentage frequency of arches in individual fingers of Right \& Left Hand.

\begin{tabular}{|l|l|l|l|}
\hline \multicolumn{5}{|c|}{ Prevalence of Arches in different digits of hands of 200 individuals } \\
\hline & Right Hand & Arch & Percentage \\
\hline S.No. & Digit of the Hand & 07 & 3.50 \\
\hline 1 & Thumb & $\mathbf{2 0}$ & $\mathbf{1 0 . 0 0}$ \\
\hline 2 & Fore-Finger/Right Index Finger & 06 & 3.00 \\
\hline 3 & Middle Finger & 01 & 0.50 \\
\hline 4 & Ring Finger & 00 & 0.00 \\
\hline 5 & Little Finger & 34 & $17 / 5=3.40$ \\
\hline & & \multicolumn{3}{l|}{} \\
\hline & Left Hand & Arch & Percentage \\
\hline & & 10 & 5.00 \\
\hline 1 & Thumb & 22 & 11.00 \\
\hline 2 & Fore-Finger/Right Index Finger & 8 & 4.00 \\
\hline 3 & Middle Finger & 2 & 1.00 \\
\hline 4 & Ring Finger & 1 & 0.50 \\
\hline 5 & Little Finger & 43 & 4.30 \\
\hline & & 77 & $3.40+4.40 / 2=3.85$ \\
\hline & Total & & \\
\hline
\end{tabular}


Average values of Percentage Frequency of Arches (overall/ all ten fingers) compiled from various studies in India, since 1963

As per this study the average value of arches in all ten fingers of 200 male subjects or 2000 prints is $\mathbf{3 . 8 5 \%}$, which is very close to the cumulative average value of ten Indian studies, which was recorded as $\mathbf{3 . 2 5 \%}$ for males and females together, and $\mathbf{3 . 5 3 \%}$ for exclusively male subjects. As the variation is less than $\mathbf{1 . 0 0} \%$ in both the scenarios, (Males\& Females together, and Males distinctly) the average percentage frequency value of current study, $3.85 \%$, can be considered valid, and highly acceptable. The detailed analysis of all eleven contemporary studies has been elaborated with the help of a table (Table No. 4).

In the Table No. 4, the results of eleven major studies (including current study), conducted in India for analysing percentage frequency of arch pattern on all ten fingers, have been complied together for the ease of analysis and comprehension:
It is clearly evident, from the above eleven (11) studies conducted between 1963 (Srivastava) and 2021 (Singh, S.P., This Study, on Males only), that there has been no consistency in the results or findings of percentage frequencies of Arches in all 10 fingers, the range has been from $1.14 \%$ to $5.10 \%$. If we calculate the average of percentage frequency values of ten (10) studies (excluding the current one, because it has included only male subjects), the answer comes out to be $3.25 \%(32.59 / 10=3.25)$, that too is nowhere close to the generally accepted $5.00 \%$ prevalence rate of Arches in humans. Now let us calculate, from the above ten (10) studies, the average value of percentage frequencies of only male subjects, the answer is $3.53 \%(35.30 / 10=3.53)$, which is very close to the cumulative average of male and female subjects, with a variation of only 0.28 percentage points, but that too is anyway closer to the generally accepted figure of $5.00 \%$ for Arches in world human population. Apart from individual findings, cumulative value of the results is also relevant because the above 10 studies represent subjects/slips from different provinces/regions of India, similar to persons/slips included in this study from 18 States/ UTs of the country.

Table No. 4. A comparison of frequency distribution of Arch (Plain Arch \& Tented Arch) pattern in various studies conducted in India, in the 21st Century.

\begin{tabular}{|c|c|c|c|c|c|c|}
\hline $\begin{array}{l}\text { S. } \\
\text { No. }\end{array}$ & Population & $\begin{array}{c}\text { Gender and no. of } \\
\text { individuals } \\
\text { Male (M)\& } \\
\text { Female (F) }\end{array}$ & $\begin{array}{l}\% \text { Frequency of Pat- } \\
\text { tern Arch in Males } \\
\text { and Females }\end{array}$ & $\begin{array}{c}\text { Average \% Fre- } \\
\text { quency of Arches } \\
\text { in Males \&Females } \\
\text { (together) }\end{array}$ & $\begin{array}{c}\% \text { Frequency of } \\
\text { Arches in Males } \\
\text { only }\end{array}$ & $\begin{array}{l}\text { Study conducted } \\
\text { by\& the year of } \\
\text { publication }\end{array}$ \\
\hline$I$ & $\begin{array}{l}\text { 10-digit Fingerprint } \\
\text { slips from eighteen } \\
\text { States/Union Terri- } \\
\text { tories of India (200 } \\
\text { Males only) }\end{array}$ & M 200 & $\begin{array}{c}\text {--- } \\
\text { (Fingerprint slips od } \\
\text { only male subjects } \\
\text { were studies/included) }\end{array}$ & $\begin{array}{c}3.85 \\
\text { (Males only) }\end{array}$ & 3.85 & $\begin{array}{c}\text { PRESENT } \\
\text { STUDY, } \\
\text { Singh, S.P. (2021) }\end{array}$ \\
\hline 1 & $\begin{array}{c}\text { Student population } \\
\text { in Mangaluru city } \\
\text { (India) }\end{array}$ & $\begin{array}{l}\text { M } 50 \\
\text { F } 50\end{array}$ & $\begin{array}{l}4.8 \\
1.6\end{array}$ & 3.2 & 4.8 & $\begin{array}{l}\text { Shimona M D, } \\
\text { Pradeep L M, } \\
\text { Bhavyashree Rai } \\
\text { (2018) [15] }\end{array}$ \\
\hline 2 & $\begin{array}{l}\text { Muslims (Central } \\
\text { India) }\end{array}$ & $\begin{array}{l}\text { M } 240 \\
\text { F } 240\end{array}$ & $\begin{array}{c}3.5 \\
5.33\end{array}$ & 4.41 & 3.5 & $\begin{array}{c}\text { Neeti Kapoor \&, } \\
\text { Ashish Badiye (2015) } \\
\text { [16] }\end{array}$ \\
\hline 3 & South Indian (India) & $\begin{array}{l}\text { M } 250 \\
\text { F } 250\end{array}$ & $\begin{array}{l}5.68 \\
4.52\end{array}$ & 5.1 & 5.68 & $\begin{array}{c}\text { Nithin et al. (2009) } \\
\text { [17] }\end{array}$ \\
\hline 4 & $\begin{array}{l}\text { Medical Students, } \\
\text { Gangtok (India) }\end{array}$ & $\begin{array}{l}\text { M } 55 \\
\text { F } 55\end{array}$ & $\begin{array}{l}4.5 \\
4.5\end{array}$ & 4.5 & 4.5 & $\begin{array}{l}\text { Kanchan et al. (2006) } \\
\text { [18] }\end{array}$ \\
\hline 5 & $\begin{array}{l}\text { Rajputs, Himachal } \\
\text { Pradesh, India }\end{array}$ & $\begin{array}{l}\text { M } 50 \\
\text { F } 50\end{array}$ & $\begin{array}{c}2 \\
1.81\end{array}$ & 1.9 & 2 & $\begin{array}{l}\text { Singh and Garg } \\
\text { (2004) [19] }\end{array}$ \\
\hline 6 & $\begin{array}{l}\text { Rarhi Brahmins } \\
\text { (Bengal) }\end{array}$ & $\begin{array}{l}\text { M } 50 \\
\text { F } 38\end{array}$ & $\begin{array}{l}2.3 \\
4.21\end{array}$ & 3.25 & 2.3 & $\begin{array}{c}\text { Chattopadhyay et al. } \\
\text { (1969) [20] }\end{array}$ \\
\hline 7 & $\begin{array}{l}\text { Danguria Tharu, } \\
\text { UP, India }\end{array}$ & $\begin{array}{l}\text { M } 379 \\
\text { F } 300\end{array}$ & $\begin{array}{l}3.87 \\
4.16\end{array}$ & 4.01 & 3.87 & Srivastava (1963) [21] \\
\hline 8 & $\begin{array}{l}\text { Rengma Nagas of } \\
\text { Nagaland (India) }\end{array}$ & $\begin{array}{l}\text { M } 104 \\
\text { F } 103\end{array}$ & $\begin{array}{l}0.49 \\
1.79\end{array}$ & 1.14 & 0.49 & $\begin{array}{c}\text { Banik et al., (2009) } \\
{[22]}\end{array}$ \\
\hline 9 & $\begin{array}{l}\text { Dhimals of North } \\
\text { Bengal (Bengal) }\end{array}$ & $\begin{array}{l}\text { M } 101 \\
\text { F } 101\end{array}$ & $\begin{array}{l}2.75 \\
1.57\end{array}$ & 2.16 & 2.75 & Biswas (2011)[23] \\
\hline 10 & $\begin{array}{l}\text { Marathi Subjects, } \\
\text { Nagpur, Maha- } \\
\text { rashtra }\end{array}$ & $\begin{array}{l}\text { M } 256 \\
\text { F } 280\end{array}$ & $\begin{array}{l}1.56 \\
4.28\end{array}$ & 2.92 & 1.56 & $\begin{array}{l}\text { Hansi D. Bansal, } \\
\text { Ashish D. Badiye, } \\
\text { \& Neeti S. Kapoor } \\
\text { (2014) [24] }\end{array}$ \\
\hline & \multirow{2}{*}{\multicolumn{3}{|c|}{ Average $\%$ Frequency of the ten studies }} & $32.59 / 10=$ & $35.30 / 10=$ & \\
\hline & & & & 3.25 & 3.53 & \\
\hline
\end{tabular}




\section{Prevalence of Patter Arch in Right Index (RI) finger of In- dian Males}

As the main objective of this paper is to analyse the prevalence of pattern Arch in Right Index (RI) finger of Indian (human) males, who as per various studies, are mainly (over 92.00\%) Dextromanual or Right - handed. In the current study the prevalence or percentage frequency of pattern Arch in Right Index (RI) fingers, has been calculated as $10.00 \%$, which means that after examining 200 Right Index (RI) fingers from 200 Ten-digit fingerprint slips of Indian adult male subjects, we found a total of 20 Right Index (RI) fingers carrying or bearing the pattern Arch. But without comparing the findings of the present (this) study, on percentage frequency of arches in Right Index (RI) fingers, with the results of other contemporary studies, conducted especially in India, the results may not seem justified or valid. Thus, the findings of this study have been compared with three most recent and relevant studies, which are by - $[15,9,25]$.

The comparative analysis of the findings will provide us with a chance to know whether the current results are in sync with the contemporary works or not. Given below, in the Table No. 6, are finding of the above three studies, along with the results of the present study for ready reference.

Out of the three studies chosen for comparison (pls. refer Table-6, above), the percentage frequency values of only one, that is, by [25], involving 166 male subjects, was found to be considerably higher, (i.e., $13.85 \%$ ), then the one derived from the present study $(10.00 \%)$. Whereas, the findings of the other two studies are almost in sync with the results of the current study. The study conducted by [15], scrutinizing fingerprints of 50 male subjects, found the percentage prevalence of pattern Arch in Right Index (RI)finger of the male subjects to be at $10.00 \%$, which is $100 \%$ match with the findings of the current study. The research conducted by [9], involving 246 male subjects, had $10.16 \%$ as the percentage prevalence of Arches in Right Index (RI) fingers, which is $98.42 \%$ match with the findings of the current study. Thorough analysis of various aspects of this study with the numerous applicable aspects of over fifteen (15) studies conducted in 19th, 20th and 21 st Century (from 1892 to 2020), would entail the final re-

Table No. 5. Distribution of Arch Pattern in Right Index (RI) Finger of 200 Adult Indian Males (Singh, S.P., Current Study, 2021).

\begin{tabular}{|c|c|c|c|}
\hline S.No. & $\begin{array}{c}\text { Total No. of Male Subjects/10-digit } \\
\text { FP Slips }\end{array}$ & $\begin{array}{c}\text { Number of Arches in Right } \\
\text { Index (RI) Fingers }\end{array}$ & $\begin{array}{c}\text { Percentage Frequency } \\
\text { on RI finger of Male } \\
\text { Subjects }\end{array}$ \\
\hline I & 200 & 20 & $10.00 \%$ \\
\hline
\end{tabular}

Table No. 6. Comparison of Distribution of Pattern Arch in Right Index (RI) Finger

Of Indian Male Subjects.

\begin{tabular}{|c|c|c|c|c|}
\hline S.No. & $\begin{array}{c}\text { Study Conducted } \\
\text { by }\end{array}$ & $\begin{array}{c}\text { Total Number } \\
\text { of Male Sub- } \\
\text { jects }\end{array}$ & $\begin{array}{c}\text { Number of Arches } \\
\text { (Plain \& Tented) in } \\
\text { RI Fingers }\end{array}$ & $\begin{array}{c}\text { \% Frequency of } \\
\text { Arches (plain } \\
\text { \& tented) in RI } \\
\text { Fingers }\end{array}$ \\
\hline 1 & $\begin{array}{c}\text { Shimona M D, } \\
\text { Pradeep L M, \& } \\
\text { Bhavyashree Rai, } \\
\text { 2018[15] }\end{array}$ & 50 & 5 & 10 \\
\hline 2 & $\begin{array}{c}\text { Aadhyyanth R Allu, } \\
\text { Sudakshina Chakra- } \\
\text { barti,2020 [9] }\end{array}$ & 246 & 25 & 10.16 \\
\hline 3 & $\begin{array}{c}\text { Abhishek Kumar } \\
\text { Tripathi, Om } \\
\text { Dubey, D. Nagesh, } \\
\text { Neha Nair, 2020 } \\
\text { [25] }\end{array}$ & 166 & 23 & 13.85 \\
\hline I & $\begin{array}{c}\text { Present/This } \\
\text { Study, Singh, S.P., } \\
\text { (2021) }\end{array}$ & $\mathbf{2 0 0}$ & $\mathbf{2 0}$ & $\mathbf{1 0}$ \\
\hline
\end{tabular}

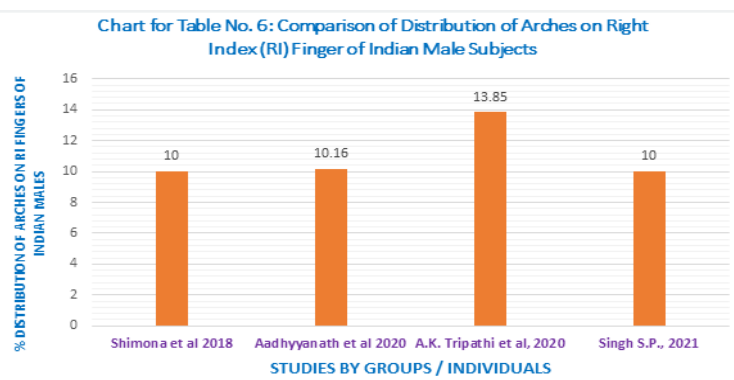


Table No. 7. Gender-wise Persons Arrested under Indian Penal Code (IPC) Crimes in States/UTs of India in the years2018\&2019 (only aged 18 and above included in this table) [26, 27].

\begin{tabular}{|c|c|c|c|c|c|}
\hline Year & $\begin{array}{c}\text { No. of } \\
\text { Males }\end{array}$ & No. of Females & $\begin{array}{c}\text { Total of Males \& } \\
\text { Female }\end{array}$ & $\begin{array}{c}\text { Percentage of Males } \\
\text { against Total No. of } \\
\text { Arrested Persons }\end{array}$ & $\begin{array}{c}\text { Percentage of Women } \\
\text { against Total No. Arrested } \\
\text { Persons }\end{array}$ \\
\hline 2018 & 3103630 & 176034 & 3279664 & 94.63 & $5.36 \%$ \\
\hline 2019 & 2886174 & 191251 & 3077425 & 93.78 & $6.21 \%$ \\
\hline \multicolumn{7}{|c|}{ Average } & $\mathbf{9 4 . 2}$ & $5.78 \%$ \\
\hline
\end{tabular}

sults of the present study acceptable to the fingerprint fraternity, and other stake holders.

\section{Percentage Participation of Indian Males and Females in Indian Penal Code (IPC) related Crimes in 2018 \& 2019}

Before reaching the conclusion on percentage prevalence of pattern Arch on the Right Index (RI) Finger of Indian male subjects, it would be pertinent to share with the researchers, the relevant crime statistics of the very recent years, especially in view of the objective of this study which is to link the percentage frequency of pattern Arch on Right Index (RI) fingers of males, to aid the analysts at the Crime Scene in India, in expeditiously accomplishing criminal identification. Aspects like handedness (right-handed, left-handed etc.), percentage participation of males/females in crimes, findings of previous studies on percentage fingerprint pattern distribution amongst populations, rarity of arch pattern etc., are crucial in drawing the conclusion. From the Table No. 7, readers will be able to observe the percentage participation of adult males and females in various crimes under Indian Penal Code (IPC). The average participation in IPC crimes, for the years, $2018 \& 2019$, for the Indian adult males was $94.20 \%$, whereas women registered only $5.78 \%$ involvement in crimes, for the same period. Not just 2018 and 2019, the analysis of crime data of previous many years would reveal that majority of crimes in India are committed by males, and it would not be very different from the average data of the two years included here.

\section{Analysis of Results}

After thorough research, analysis of data, and comparison of finding of this study with relevant noncurrent, and contemporary studies, following inference have been drawn:

The average percentage prevalence of Arches (in all 10 fingers) in 200 Indian human males was calculated to $3.85 \%$.

The percentage frequency of pattern Arch in Right-Index (RI) finger of Indian human male subjects, observed in this study is $10.00 \%$, which is $100 \%$ and $98.42 \%$ match with two out of three relevant studies undertaken in Indian in the year 2018 and 2020.

Furthermore, the probability of the chance print originating squarely from right hand of an Indian male is over $92.00 \%$ (as more than $92.00 \%$ Indian Males are Right-handed). Besides, the chance of the crime being committed in India by adult male is 94.20\%; percentage participation of males in Indian Penal Code related crimes was $94.20 \%$ (cumulative figure of 2018 \& 2019). The above statistical analysis pertaining to an arch impression at the scene of crime, can certainly help the analysts in expedit- ing the process of comparison by firstly choosing lesser number of 10-digit fingerprint cards/slips of the suspects, and identifying the criminal from the list of probable culprits. If the expert doesn't find the culprit in the shortened list of inclusions, only then they may proceed for involving more suspects' slips from the excluded ones.

\section{Conclusions and Future Work}

The results of this study may provide a cue to the fingerprint analysts, who after lifting the chance print from the scene of crime, have to compare it with a large set of ten-digit fingerprint slips/ cards of the suspects, or/and previous records, which is a very tedious and time-consuming process. A slow pace of comparison due to large number of suspects, or work overload, can lead to delay in the identification of the criminal. Moreover, such a situation may provide the culprit with a chance to flee from the state (province) or the country. This study on prevalence of pattern arch in Right Index (RI) finger of Indian males, intends to assist the analysts or the fingerprint technicians, reduce the time in comparison, by initially including or selecting lesser number of suspects' slips, on the basis of the prevalence rate, as cue or hint. Although every scene of crime is unique, and there is no sure shot method of analysing it, and nailing the culprit, but we do keep trying, and find ways to shorten the lengthy process of fingerprint-based individualisation, for faster delivery of justice to the victim/s of the crime.

It's is always better to have a greater number of studies, with bigger sample sizes, to have better understanding of an issue in hand, be it determination of pattern type on individual fingers or all ten digits of the hands. Further studies with bigger data sizes conducted in India, and other parts of the world, would certainly help in further validating the findings of this study.

\section{References}

[1]. www.universitystory.gla.ac.uk. Cited as 2021 May 06. Available at:

[2]. Kapoor N, Badiye A. Digital dermatoglyphics: A study on Muslim population from India. Egyptian Journal of Forensic Sciences. 2015 Sep 1;5(3):905.

[3]. www.forensicsciencesimplified.org. Cited as 2021 May 13. Available at:

[4]. Francis Galton, Finger Prints, The Classic 1892 Treatise, (The Dover edition, first published in 2005, a republication of the work originally published by Macmillan and Co., London. In 1892), Dover Publication Inc., Mineola, NY 11501.

[5]. Chatterjee SK, Hague Richard V. Fingerprint or Dactyloscopy and Ridgeology, Published by Srijib Chatterjee, 17, Lake Avenue, Calcutta-700026, India, 1988; 97.

[6]. B. Lakshamanan, Arun G Bhoi. AFIS: Studies for The Frequency of Appearances of Finger Print Patterns in Human Fingers, J. Foren. Crime Inv. 2014; 10-13.

[7]. Banik SD, Pal P, Mukherjee DP. Finger dermatoglyphic variations in Rengma Nagas of Nagaland India. Coll Antropol. 2009 Mar;33(1):31-5. Pubmed 
PMID: 19408600.

[8]. Niall McCarthy, Handedness, The Countries with The Most Left-Handed People, 2020 Feb 4.

[9]. Aadhyyanth R Allu, Sudakshina Chakrabarti. Fingerprint patterns of thumb and index in the right and left-handed male and female medical and paramedical students, Int. J. Res. Pharm. Sci., 2020; 11(2): 64-70.

[10]. Finger Prints in India 2016, Central Finger Print Bureau, National Crime Records Bureau, Ministry of Home Affairs, Govt. of India, New Delhi, 2018 June: 112-113.

[11]. Singh SP. A Glossary of terms, Concepts and Abbreviations, Selective and Scientific Books, New Delhi, India, August 2019.

[12]. U.S. Department of Justice (2013). Crime Scene Investigation: A Guide for Law Enforcement cited as 2021 May 13. Available at:

[13]. https://en.wikipedia.org/wiki/Crime_scene. Cited as 2021 May 19.

[14]. http://assets.publishing.service.gov.uk/government/uploads/system/uploads/attachment_data/file/267523/FingerprintTerminology. Cited as 2021 May 19.

[15]. Shimona MD, Pradeep LM, Bhavyashree Rai. Determination of Hand of Origin of Fingerprints by Analysing Fingerprint Characteristics of Whorl Patterns. J Forensic Sci \& Criminal Inves 2018; 9(3): 555761.

[16]. Kapoor N, Badiye A. Digital dermatoglyphics: A study on Muslim population from India. Egyptian Journal of Forensic Sciences. 2015 Sep 1;5(3):905 .

[17]. Nithin MD, Balaraj BM, Manjunatha B, Mestri SC. Study of fingerprint classification and their gender distribution among South Indian population. J Forensic Leg Med. 2009 Nov;16(8):460-3. Pubmed PMID: 19782316.
[18]. Kanchan T, Chattopadhyay S. Distribution of fingerprint patterns among medical students. Journal of Indian Academy of Forensic Medicine. 2006;28(2):65-8.

[19]. Singh I, Garg RK. Finger dermatoglyphics: a study of the Rajputs of Himachal Pradesh. The Anthropologist. 2004 Apr 1;6(2):155-6.

[20]. Chattopadhyay PK, Sharma PD. Finger dermatoglyphics of the Rarhi Brahmins of Bengal. Am J Phys Anthropol. 1969 May;30(3):397-401. Pubmed PMID: 5791016.

[21]. Srivastava RP. Study of finger prints of the Danguria Tharu of Uttar Pradesh (India). Am J Phys Anthropol. 1963 Mar;21(1):69-76. Pubmed PMID: 13978611.

[22]. Banik SD, Pal P, Mukherjee DP. Finger dermatoglyphic variations in Rengma Nagas of Nagaland India. Coll Antropol. 2009 Mar;33(1):31-5. Pubmed PMID: 19408600.

[23]. Biswas S. Finger and palmar dermatoglyphic study among the Dhimals of North Bengal, India. The Anthropologist. 2011 Jul 1;13(3):235-8.

[24]. Bansal HD, Hansi D, Badiye AD, Kapoor NS. Distribution of fingerprint patterns in an Indian population. Malaysian Journal of Forensic Sciences. 2014 Dec;5(2):18-21.

[25]. Tripathi AK, Dubey O, Nagesh D, Nair N. Analysis of Fingerprint Pattern Distribution Framework of Telugu Population in India. Journal of Critical Reviews. 2020;7(17):1851-60.

[26]. Crime in India-2018, National Crime Records Bureau, M/o Home Affairs, Govt. of India, New Delhi. Cited as July 2021.

[27]. Crime in India-2019, National Crime Records Bureau, M/o Home Affairs, Govt. of India, New Delhi. Cited as July 2021. 